\title{
A study on effects of knowledge management on the success of customer relationship management
}

\author{
Mahtab Hassani $^{a}$, Elham Aghaalikhani ${ }^{\mathrm{b}}$, Masoud Hassanabadi ${ }^{\mathrm{b}^{*}}$ and Mostafa Shakouri Rad $^{\mathrm{b}}$
}

${ }^{a}$ Islamic Azad University, Central Tehran Branch, Executive Management on Marketing, Iran

${ }^{b}$ Department of Management, Islamic Azad University, South Tehran Branch, Tehran, Iran

\begin{tabular}{l}
\hline C H R O N I C L E \\
\hline Article history: \\
Received May 12, 2013 \\
Received in revised format \\
25 June 2013 \\
Accepted 12 August 2013 \\
Available online \\
August 15 2013 \\
\hline Keywords: \\
CRM \\
Customer satisfaction \\
Knowledge \\
Trust \\
Customer loyalty
\end{tabular}

\section{A B S T R A C T}

\begin{abstract}
Nowadays, it is widely accepted that knowledge is the primary source of adding more value to organizations and business units. Customer relationship management (CRM), on the other hand is the main bridge for building a connection between management team and users and a good CRM also contributes to firms in terms of customer retention and getting more market share through word of mouth advertisement. In this paper, we present an empirical investigation to find the effect of knowledge on CRM in one of Iranian banks. The proposed study selects a sample of 384 randomly selected people and distributes a questionnaire among them. Cronbach alphas for all components of the survey have been well above 0.70 , which validates the overall questionnaire. The results have confirmed that knowledge influences CRM positively in terms of customer satisfaction, customer loyalty and trust.
\end{abstract}

(c) 2013 Growing Science Ltd. All rights reserved.

\section{Introduction}

Customer relationship management (CRM) plays an important role on the success of business development and there are literally many studies concentrated on the success of CRM implementation on the success of business. Azad and Darabi (2013), for instance, performed an empirical investigation on how CRM influences marketing planning in telecommunication industry. In their survey, they re-examined the impact of having efficient CRM on efficiency of a telecommunication company by considering three hypotheses: The first hypothesis investigated whether implementation of CRM could contribute to customer's perception in terms of customer retention, satisfaction, loyalty and awareness. The second hypothesis tried to find out whether implementation of CRM could impact on market performance in terms of reduction on customer complaints, quality improvement, improving customer perception, access to services and increase in market share. Finally, the third

*Corresponding author. Tel: +989123797648

E-mail address: masoud.hassanabadi84@gmail.com (M. Hassanabadi) 
hypothesis investigated the impact of CRM on financial figures in terms of sales growth, profit growth, earnings per share and productivity. The results of their investigation confirmed the first hypothesis and rejected the third hypothesis.

Hosseini et al. (2013) performed an investigation on relationship between CRM and organizational learning through knowledge management in a case study of Tehran travel agency. They reported that there was a meaningful relationship among components of CRM including organizational learning, and knowledge management in this travel agency.

Baksi (2013) studied the link between automated service quality, customer satisfaction and behavioral intentions with CRM performance indexing approach through empirical evidence from Indian banking industry. The study used structural equation modeling (SEM) to assess and validated the nomological relationship between the variables.

Sehhat (2013) performed a survey on important factors influencing brand equity in a case study of banking industry. He explained that one of the most important issues in increasing customers' requirements is to increase the quality of services through providing better quality services. Customer satisfaction is one of the primary needs to meet people's needs and to have an efficient CRM we require to detect the most important factors influencing efficiency and effectiveness in banking industry. He tried to reach three objectives: The study first detected important factors, which build customers' perception towards CRM, then he detected all influencing factors, which influence CRM, and finally, he evaluated the effect of CRM towards brand equity. The proposed study first designed a questionnaire and distributed it among 386 customers. Using structural equation modeling and certified factor analysis, he analyzed the results. The results indicated that three factors including information, employee job behavior and suggestions and other factor had meaningful impact on customer brand equity. However, the impact of equipment on customer brand equity was not meaningful.

Mirzamohammadi and Basirat Fard (2012) investigated factors affecting productivity and the role of CRM in a case study of home appliance manufacturing. They presented the decentralized supply chain with two suppliers and two competing retailers. The study also investigated the sourcing and pricing strategies of two retailers in a decentralized supply chain system under a supply disruption environment. These retailers face their individual stochastic demand markets; however, they compete with each other through a two-stage price and service operation. The interactive dynamics among retailers was characterized, including the existence and uniqueness of the Nash Equilibrium in service and price games demonstrated.

Yazdanpanah and Gazor (2013) presented an empirical investigation for detecting success factors of electronic CRM (e_CRM) system to establish an appropriate model in police call center of Iran. They explained factors influencing the success of eCRM system in police telephone-contact centers as a part of their interactive and relationship-oriented programs. In their study, one of the most famous models implemented in several industries such as insurance industry has been evaluated; the results then were modified for application. The results, in fact, corroborated the main hypothesis, which pointed to the existence of a relationship between an establishment and its institutional success. In other words, having established an eCRM system, institutions will witness an increase in efficiency, staff satisfaction, and eventually customer satisfaction.

\section{The proposed study}

This paper presents a method to study the effect of knowledge on CRM and Fig. 1 demonstrates the proposed framework of our study. 


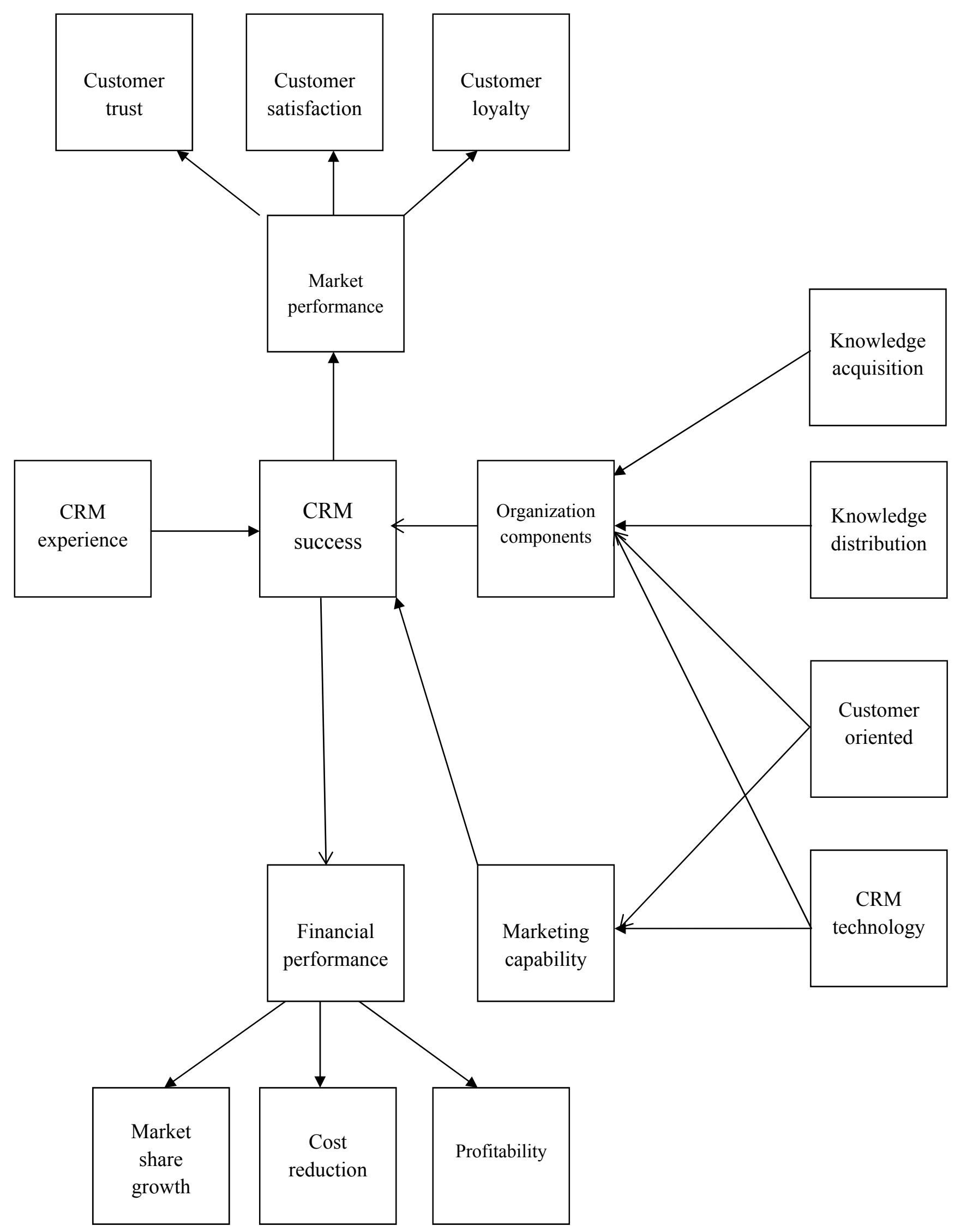

Fig. 1. The proposed framework of the study 
Based on the proposed framework of the study, we consider the following hypotheses based on the implementation of path analysis.

1. Knowledge acquisition influences positively on organizational components.

2. Knowledge distribution influences positively on organizational components.

3. Customer orientation influences positively on organizational components.

4. CRM technology influences positively on organizational components.

5. Customer orientation influences positively on marketing capabilities.

6. CRM technology influences positively on marketing capabilities.

7. Organizational components influences positively on the success of CRM.

8. Marketing capabilities influences positively on the success of CRM.

9. Past good experiences on CRM positively influences on the success of CRM.

10. CRM success influences positively on financial performance.

11. CRM success influences positively on marketing performance.

The proposed study has accomplished among regular customers of bank Melli Iran in city of Tehran, Iran and the sample size is calculated as follows,

$N=Z_{\alpha / 2}^{2} \frac{p \times q}{e^{2}}$

where $N$ is the sample size, $p=1-q$ represents the probability, $z_{\alpha / 2}$ is CDF of normal distribution and finally $\varepsilon$ is the error term. For our study we assume $p=0.5, z_{\alpha / 2}=1.96$ and $e=0.99$, the number of sample size is calculated as $N=384$. The survey was accomploshed in 2011 among regular customers of this bank.

Fig. 2. Demonstrates the summary of personal characteristics of the participants. In our survey, $69 \%$ of the participants were male and the remaining 31 were female.

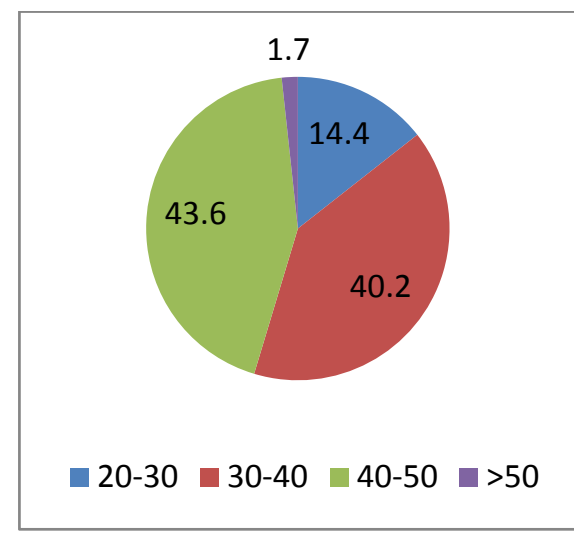

Age

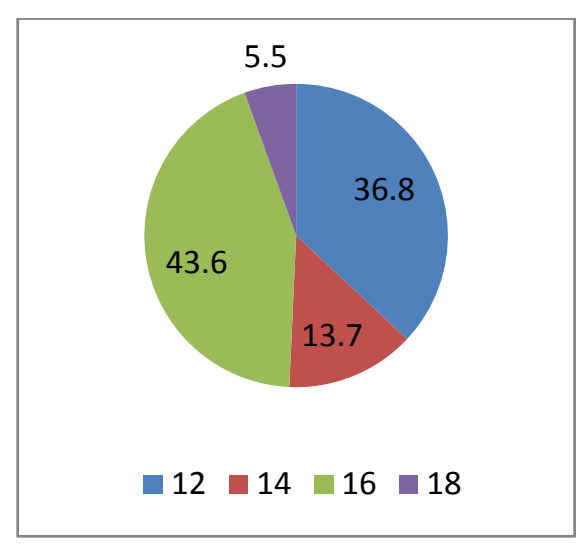

Years of education

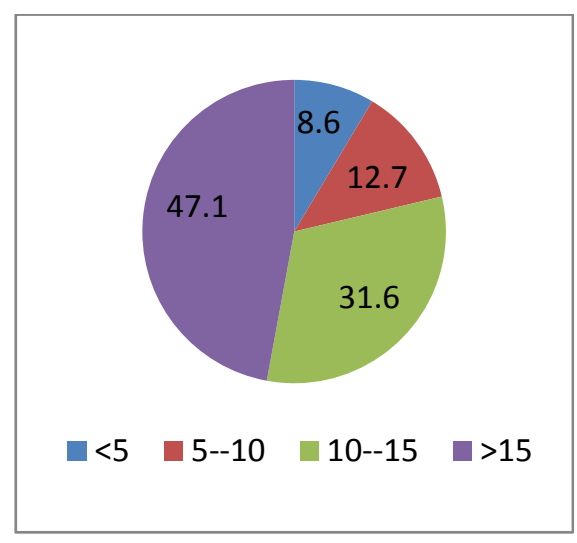

Job experience

Fig. 1. Personal characteristics of the participants

Table 1 demonstrates Cronbach alpha for the proposed study of this paper. As we can observe from the results of Table 1, all components are well above the minimum desirable level of 0.70 . In addition, KMO test and Bartlett test are also 0.937 and 7559.769, which also confirm the results of our survey when the level of significance is five percent. 
Table 1

The summary of Cronbach alpha for components of the survey

\begin{tabular}{lllllllllll}
\hline Component & $\begin{array}{l}\text { Knowledge } \\
\text { acquisition }\end{array}$ & $\begin{array}{l}\text { Knowledge } \\
\text { distribution }\end{array}$ & $\begin{array}{l}\text { CRM } \\
\text { technology }\end{array}$ & $\begin{array}{l}\text { CRM } \\
\text { experience }\end{array}$ & $\begin{array}{l}\text { Customer } \\
\text { oriented }\end{array}$ & $\begin{array}{l}\text { Marketing } \\
\text { capabilities }\end{array}$ & $\begin{array}{l}\text { Financial } \\
\text { performance }\end{array}$ & $\begin{array}{l}\text { Organizational } \\
\text { components }\end{array}$ & $\begin{array}{l}\text { CRM } \\
\text { success }\end{array}$ & $\begin{array}{l}\text { Total } \\
0.732\end{array}$ \\
\hline Cronbach $\alpha$ & 0.813 & 0.839 & 0.774 & 0.771 & 0.815 & 0.877 & 0.729 & 0.728 & 0.940 \\
\hline
\end{tabular}

Next, we present details of our findings on testing various hypotheses in Table 2.

Table 2

The summary of testing various hypotheses of the survey

\begin{tabular}{lrrrc}
\hline Invested path & Coefficient & t-value & Result & \multicolumn{2}{c}{ Past experience } \\
\hline Knowledge acquisition $\rightarrow$ Organizational components & -0.25 & -1.20 & Reject & Reject \\
Knowledge distribution $\rightarrow$ Organizational components & -0.07 & -0.43 & Reject & Reject \\
Customer orientation $\rightarrow$ Organizational components & 0.16 & 0.68 & Reject & Reject \\
CRM technology $\rightarrow$ Organizational components & 0.10 & 0.54 & Reject & Reject \\
Customer orientation $\rightarrow$ Marketing capabilities & 0.69 & 5.16 & Confirmed & Confirmed \\
CRM technology $\rightarrow$ Marketing capabilities & 0.17 & 1.26 & Reject & Confirmed \\
Organizational components $\rightarrow$ Success of CRM & 0.99 & 21.30 & Confirmed & Confirmed \\
Marketing capabilities $\rightarrow$ Success of CRM & -0.01 & -0.63 & Reject & Confirmed \\
Past good experiences $\rightarrow$ Success of CRM & -0.02 & -0.95 & Reject & Confirmed \\
Success of CRM $\rightarrow$ financial performance & -0.01 & -0.13 & Reject & Reject \\
Success of CRM $\rightarrow$ Marketing performance & -0.19 & -3.19 & Confirmed & Confirmed \\
\hline
\end{tabular}

As we can observe from the results of Table 2, the first four hypotheses have been reject, which means that none of four components of knowledge acquisition, knowledge distribution, customer orientation and CRM technology influences organizational components. The results of this part of the survey are consistent with previous findings in the literature (Sin et al., 2005; Jain \& Singh, 2002). In addition, in our survey, customer orientation influences positively on marketing capabilities, organizational components influence the success of CRM implementation and the success of CRM influences on marketing performance. These two results are also consistent with what we have seen in the literature (Yau et al., 2000; Dyche, 2002). However, the survey did not find enough evidence to believe that either marketing capabilities or past good experiences but these could influence success of CRM positively although the other researchers have reported such relationships (Ryals \& Knox, 2001).

\section{Conclusion}

In this paper, we have presented an empirical investigation to find the effect of knowledge on the success of customer relationship management. The study used path analysis to examine various hypotheses and the results of our survey have confirmed that customer orientation influences positively on marketing capabilities, organizational components influence the success of CRM implementation and the success of CRM influences on marketing performance. However, the survey did not find enough evidence to believe that either marketing capabilities or past good experiences but these could influence success of CRM positively although the other researchers have reported such relationships.

\section{References}

Azad, N., \& Darabi, K. (2013). A study on how CRM influences marketing planning in telecommunication industry. Management Science Letters, 3(8), 2323-2326.

Baksi, A.K. (2013). Exploring nomological link between automated service quality, customer satisfaction and behavioural intentions with CRM performance indexing approach: Empirical evidence from Indian banking industry. Management Science Letters, 3(1), 1-22.

Dyche, J. (2002). The CRM handbook. Pearson Education India. 
Jain, D., \& Singh, S. S. (2002). Customer lifetime value research in marketing: A review and future directions. Journal of Interactive Marketing, 16(2), 34-46.

Hosseini, M.H., Nemati, B., Sadeghi, N. (2013). An investigation on relationship between CRM and organizational learning through knowledge management: A case study of Tehran travel agency. Management Science Letters, 3(3), 999-1006.

Mirzamohammadi, S., \& Basirat Fard, F. (2012). Factors affecting productivity and the role of customer relationship management: A case study of home appliance manufacturing. Management Science Letters, 2(1), 55-66.

Ryals, L., \& Knox, S. (2001). Cross-functional issues in the implementation of relationship marketing through customer relationship management. European Management Journal, 19(5), 534-542.

Sehhat, S. (2013). A survey on important factors influencing brand equity: A case study of banking industry. Management Science Letters, 3(1), 315-320.

Sin, L. Y., Alan, C. B., \& Yim, F. H. (2005). CRM: conceptualization and scale development. European Journal of Marketing, 39 (11/12), 1264-1290.

Yau, O. H., Lee, J. S., Chow, R. P., Sin, L. Y., \& Tse, A. C. (2000). Relationship marketing the Chinese way. Business Horizons, 43(1), 16-24.

Yazdanpanah, A.A., \& Gazor, H. (2012). Detecting success factors of electronic customer relationship management (e_CRM) system to establish an appropriate model in police call centre of Iran. Management Science Letters, 2(1), 339-350. 